Figure S1. Phylogenetic trees of BTLs and Rabring7/BCA2s based on concatenated RING-H2 and BZF domains.

BTLs Phylogeny.

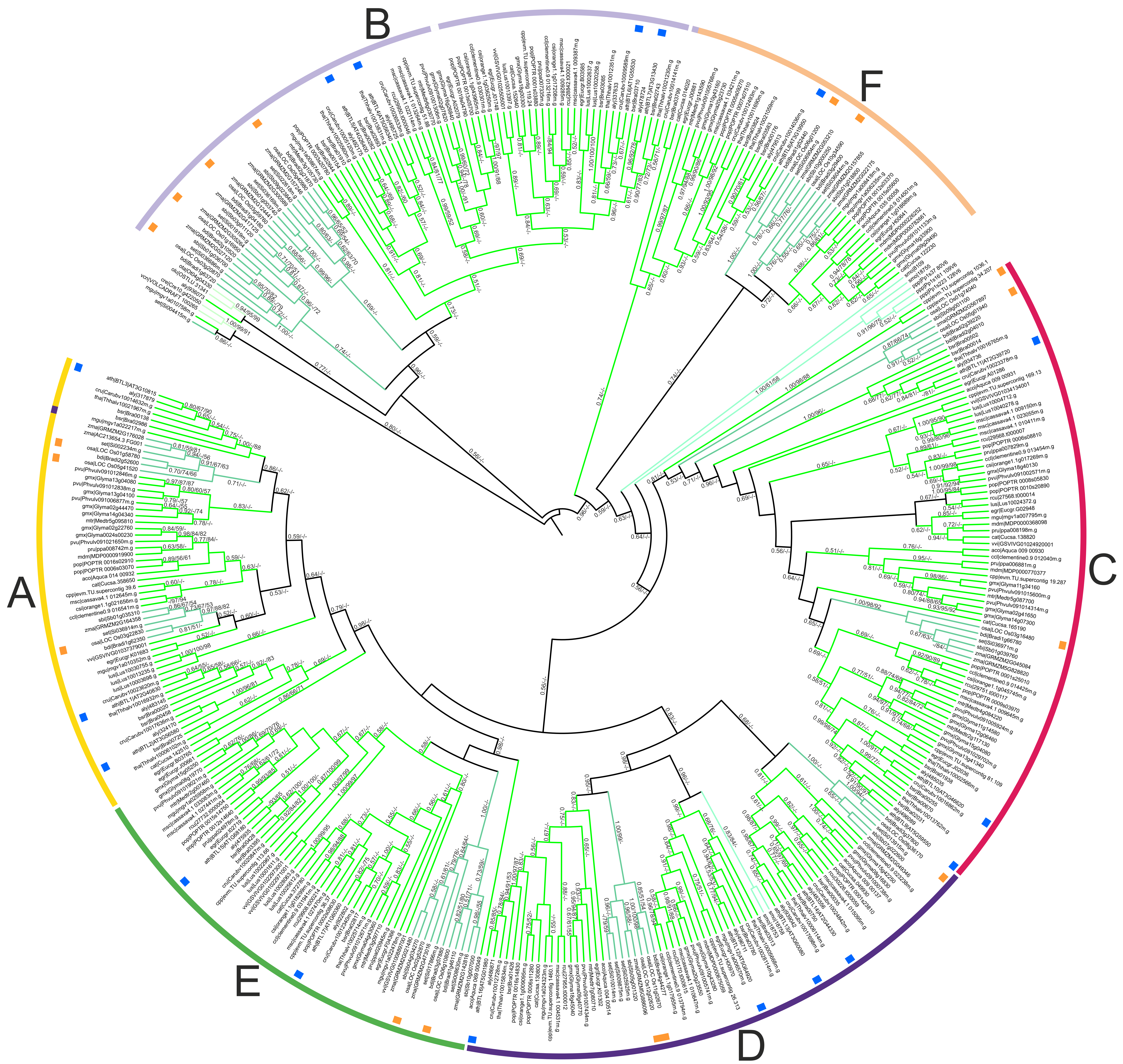


Figure S1. (continued).

\section{Rabring7/BCA2s Phylogeny.}

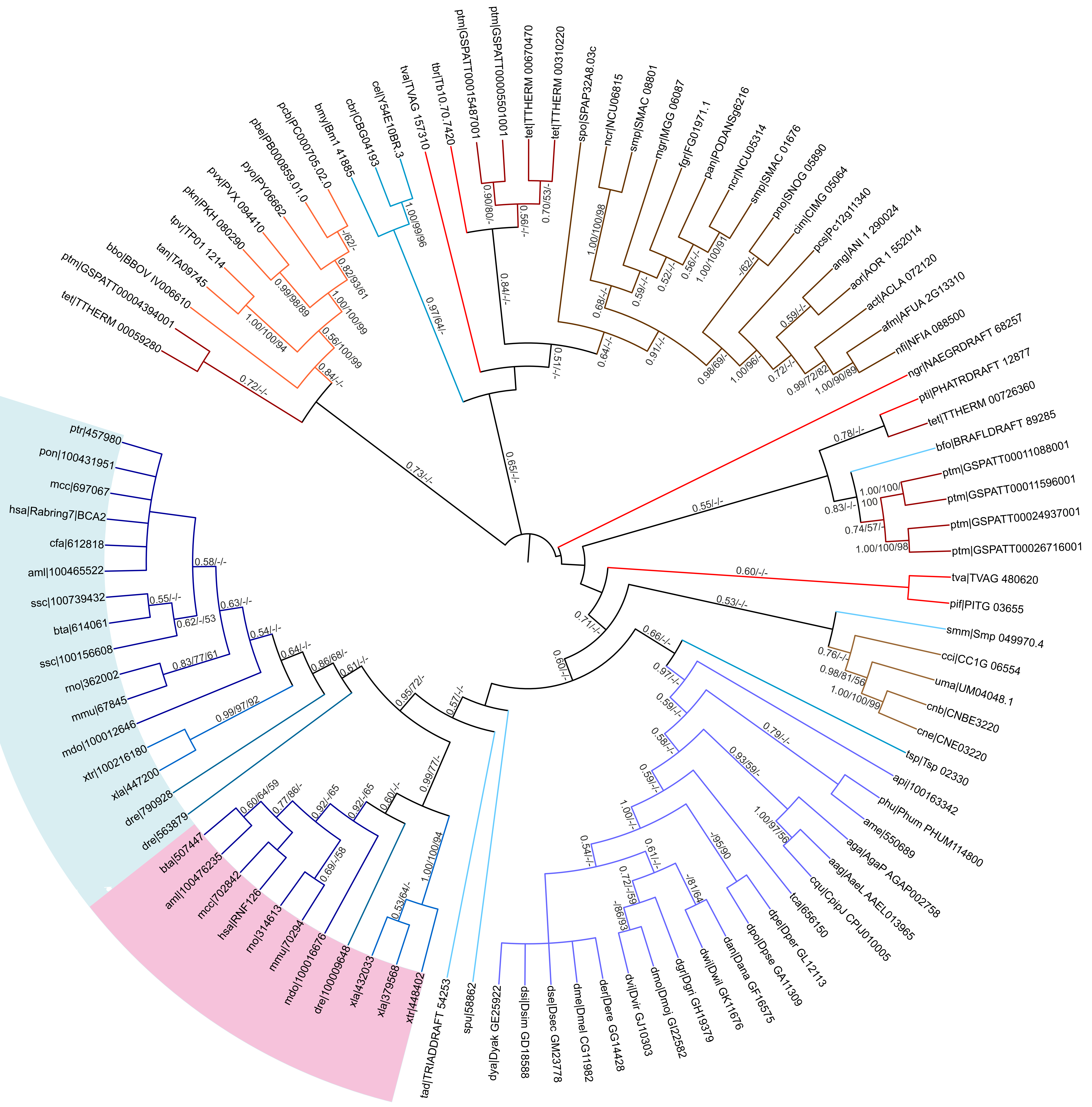

